\title{
PEMBANGUNAN OLAHRAGA KOTA SELONG KABUPATEN LOMBOK TIMUR DITINJAU DARI SPORT DEVELOPMENT INDEX
}

(Studi Evaluasi Ketersediaan Ruang Terbuka, Partisipasi Masyarakat Dalam Berolahraga)

\author{
Didik Daniyantara $^{1}$, Suryansah $^{2}$ \\ email: daniyantara_didik@yahoo.com${ }^{1}$, suryansahtkd@yahoo.com ${ }^{2}$ \\ Program Studi Pendidikan Jasmani Kesehatan dan Rekreasi, Fakultas Ilmu Pendidikan, \\ Universitas Hamzanwadi ${ }^{1,2}$
}

\begin{abstract}
Abstrak
Penelitian ini bertujuan untuk mengkaji ketersediaan ruang terbuka olahraga, dan tingkat partisipasi masyarakat dalam berolahraga di Kota Selong Kabupaten Lombok Timur. Penelitian merupakan jenis penelitian deskriptif kuantitatif dimana hasil yang diperoleh didapatkan melalui instrument penelitian berupa observasi untuk memperoleh data ketersediaan lahan atau ruang terbuka untuk berolahraga, angket/quisioner untuk memperoleh data tentang tingkat partisipasi masyarakat dalam melakukan kegiatan olahraga. Dari penelitian yang dilakukan, telah diperoleh hasil bahwa pembangunan olahraga di kota selong masih tergolong rendah, ini terlihat dari Hasil pembangunan olahraga Kota Selong disimpulkan sebagai berikut: 1) Nilai indeks ruang terbuka adalah 0,411, nilai ini jika ditinjau dari norma SDI berada pada kategori rendah, artinya bahwa ketersediaan ruang terbuka olahraga di kota Selong belum cukup tersedia. 2). Nilai indeks Partisipasi adalah 0,332, berdasarkan norma SDI masih berada pada kategori rendah, artinya bahwa tingkat partisipasi masyarakat dalam berolahraga masih rendah. dari nilai indeks tersebut maka didapatlah nilai indeks pembangunan olahraga kota selong yaitu 0,302 , nilai ini jika ditinjau dari norma SDI berada pada rentang angka 0,000-0,499, artinya bahwa pembangunan olahraga kota Selong masih berada pada kategori rendah.
\end{abstract}

Kata Kunci: Pembangunan Olahraga, Ruang Terbuka, Partisipasi Masyaraka

\begin{abstract}
This study aims to examine the availability of sports open space, and the level of community participation in sports in Selong City, East Lombok Regency. Research is a quantitative descriptive research where the results obtained are obtained through research instruments in the form of observations to obtain data on the availability of land or open space for exercise, questionnaires/ questionnaires to obtain data on the level of community participation in sports activities. From the research conducted, results have been obtained that the development of sports in the city of Selong is still relatively low, this can be seen from the results of the City Selong sports development concluded as follows: 1) The open space index value is 0.411, this value when viewed from the SDI norm is in the low category, meaning that the availability of open space for sports in the city of Selong is not yet sufficiently available. 2). The Participation index value is 0.332, based on SDI norms it is still in the low category, meaning that the level of community participation in exercise is still low. from the index value, it is obtained that the Selong City sports development index value is 0.302, this value if viewed from the SDI norm is in the range of 0,000-0,499, meaning that the development of the sport in the city of Selong is still in the low category.
\end{abstract}

Keywords: Sports Development, Open Space, Community Participation 


\section{A. Pendahuluan}

Evaluasi kebijakan dapat menyangkut perspektif yang lebih luas, sebagaimana dinyatakan oleh Thomas R.Dye (dalam Hamdi M, 2014: 107) bahwa evaluasi kebijakan merupakan pembelajaran mengenai konsekuensi dari kebijakan publik (learning about the consequences of public policy). Untuk mengevaluasi hasil pembangunan olahraga Kabupaten Lombok Timur secara umum dan Kota Selong secara khusus maka perlu dilakukan penelitian studi evaluasi. Dari segi waktu evaluasi kebijakan dibedakan atas evaluasi kebijakan formatif dan evaluasi kebijakan sumatif. Evaluasi kebijakan formatif adalah evaluasi kebijakan yang dilakukan terhadap kebijakan yang sedang diimplementasikan, dan berfokus pada penilaian tentang seberapa efektif suatu kebijakan dilaksanakan. Menurut Rossi dan Freeman (dalam hamdi M, 2014: 108) menyatakan bahwa evaluasi formatif diarahkan pada 3 pertanyaan yakni, seberapa jauh program dapat mencapai kelompok sasaran yang telah ditentukan?, apakah pemberian pelayanan konsisten dengan spesifikasi desain program?, dan apakah sumber daya yang sedang dan telah digunakan dalam pelaksanaan program? Sedangkan evalusi kebijakan sumatif adalah evaluasi yang dilakukan pada saat implementasi sudah selesai dilakukan, dan berfokus pada penilaian tentang sejauh mana hasil dan dampak pelaksanaan kebijakan memberikan kontribusi pada pencapaian tujuan kebijakan (Hamdi M, 2014: 108). Jadi, untuk mengetahui sudah sejauh mana pencapaian pembangunan olahraga di Kota Selong tentunya harus mengevaluasi 4 aspek yang menjadi indikator pembangunan olahraga nasional, yakni ruang terbuka, partisipasi masyarakat, sumber daya manusia, dan tingkat kebugaran jasmani masyarakat. Jika Human Development Index digunakan untuk mengukur hasil pembangunan manusia, maka Sport Development Index adalah metode untuk mengukur hasil pembangunan olahraga.Tolak ukur pembangunan olahraga yang digunakan oleh para pengambil kebijakan,pada masa lalu selalu mengacu pada prestasi cabang olahraga tertentu.Prestasi tersebut kemudian diperkuat dengan perolehan simbol-simbol kemenangan dalam bentuk medali maupun piala bergilir dengan hasil kemenangan, Dengan demikian kerangka pemikiran yang digunakan selalu berujung pada upaya-upaya memperoleh medali kemenangan sebanyak-banyaknya, Semakin banyak medali yang dapat atau diraih, maka semakin menonjol prestasi olahraga di suatu daerah, Setiap daerah akan berusaha mengungguli daerah lain dengan menunjukkan jumlah medali. Dengan tidak meninggalkan tolok ukur medali kemenangan sebagai cara melihat keberhasilan pembinaan prestasi olahraga, maka indikator keberhasilan pembangunan olahraga yang lebih menyeluruh dan mendasar perlu lebih dikedepankan, Indikator keberhasilan pembangunan olahraga mengacu pada dimensi: (1) partisipasi, (2) ruang terbuka,(3) kebugaran,dan (4) sumber daya manusia, Keempat dimensi gabungan tersebut mencerminkan keberhasilan pembangunan olahraga yang kemudaian lazim disebut sebagai Sport Development Index (Maksum, dkk, 2004).

\section{B. Metode}

Jenis penelitian ini adalah penelitian evaluatif atau penelitian evaluasi. Menurut (Arikunto.S, 2010:36) jenis penelitian ini dapat diterapkan pada objek-objek jika peneliti ingin mengetahui kualitas dari suatu kegiatan.Penelitian evaluasi menuntut persyaratan yang harus dipenuhi, yaitu adanya kriteria, tolak ukur, atau standar yang digunakan sebagai pembanding bagi data yang diperoleh, setelah data tersebut diolah dan merupakan kondisi nyata dari objek yang diteliti.Kesenjangan antara kondisi nyata dengan kondisi harapan yang dinyatakan dalam kriteria itulah yang dicari.Dari kesenjangan tersebut diperoleh gambaran apakah objek yang diteliti sudah sesuai, kurang sesuai, atau tidak sesuai dengan kriteria. Penelitian evaluasi bermaksud mengumpulkan data tentang implementasi kebijakan, dengan demikian manfaat hasil penelitiannya juga untuk pihak yang membuat kebijakan (Arikunto $\mathrm{S}$, 2010: 37). 
1. Ruang terbuka, peneliti akan memfokuskan pada prasarana olahraga seperti stadion standar untuk sepakbola dan nomor-nomor atletik, gedung olahraga, kolam renang, lapangan-lapangan olahraga futsal, voli, takraw, tennis, badminton, basket, baik indoor maupun outdoor, sirkuit, dan jalur jogging. Ketika ingin menghitung indeks ruang terbuka, maka yang pertama dilakukan adalah menghitung rasio luas ruang terbuka olahraga dibagi dengan jumlah penduduk yang berusia 7 tahun keatas untuk mendapatkan niai katual. Angka standar ruang terbuka adalah $3,5 \mathrm{~m}^{2}$ per orang. Artinya nilai maksimum luas ruang terbuka adalah $3,5 \mathrm{~m}^{2}$ dan nilai minimum adalah $0 \mathrm{~m}^{2}$. Setelah semua angka didapatkan kemudian dihitung dengan menggunakan rumus:

$$
\text { Indeks Ruang Terbuka }=\frac{\text { Nilai Aktual }- \text { Nilai Minimum }}{\text { Nilai Maksimum }- \text { Nilai Minimum }}
$$

2. Partisipasi, peneliti akan memfokuskan pemberian angket kepada sampel yang akan melaksanakan tes kebugaran jasmani. Nilai aktual partisipasi diukur berdasarkan rasio antara peserta tes yang melakukan aktifitas olahraga minimal 3 kali dalam seminggu dengan jumlah sampel yang diambil pada suatu daerah. Nilai maksimum partisipasi adalah 100 sesuai dengan yang ditetapkan dalam SDI, dan nilai minimumnya adalah 0. Setelah semua angka didapat kemudian dihitung dengan menggunakan rumus :

$$
\text { Indeks Partisipasi }=\frac{\text { Nilai Aktual }- \text { Nilai Minimum }}{\text { Nilai Maksimum }- \text { Nilai Minimum }}
$$

Setelah semua nilai indeks dari kedua indikator pembangunan olahraga didapatkan maka tahap terakahir adalah penghitungan indeks secara keseluruhan dengan menggunakan rumus:

$$
\begin{aligned}
\mathrm{SDI}= & \frac{1}{4}(\text { Indeks Ruang terbuka })+\frac{1}{4}(\text { Indeks Partisipasi })+ \\
& \frac{1}{4}(\text { Indeks SDM })+\frac{1}{4}(\text { Indeks Kebugaran }
\end{aligned}
$$

\section{Hasil dan Pembahasan}

Dari hasil penelitian yang diperoleh di lapangan berdasarkan indicator pembangunan olahraga yakni, ketrsediaan ruang tebuka dan partisipasi masyarakat diperoleh hasil sebagai berikut:

1. Ketersediaan Ruang Terbuka

Nilai indeks ketersediaan ruang terbukadi kota Selong adalah 0,411, indeks nilai ini jauh lebih tinggi dari nilai indeks ruang terbuka nasional yaitu 0,215, namun jika ditinjau dari norma SDI nilai ini masih berada di bawah angka 0,499, artinya bahwa ketersediaan ruang terbuka kota Pontianak masih berada pada kategori Rendah.

2. Nilai indeks partisipasi masyarakat

Partisipasi masyarakat kota Selong adalah 0,332, jika ditinjau dari norma Sport Development Index (SDI) nilai ini masih berada dibawah angka 0,499, artinya bahwa tingkat Partisipasi Masyarakat kota Selong masih berada pada kategori Rendah. 


\section{Simpulan}

Secara umum penelitian ini telah sesuai dengan tujuan yang diharapkan yaitu untuk mengetahui kemajuan pembangunan olahraga kota Selong. Berdasarkan permasalahan dan tujuan yang dipaparkan dalam penelitian ini, kemudian dikaitkan dengan hasil temuan penelitian dan pembahasannya, maka secara garis besar dapat di buat beberapa kesimpulan sebagaiberikut:

1. Indeks ruang terbuka Kota Selong adalah 0,411. Nilai indeks ini lebih tinggi dibandingkan nilai indeks ruang terbuka nasional yang hanya 0,215 . Namun jika ditinjau dari SportDevelopment Index dan berdasarkannorma SDI, nilai indeks ini masih berada pada rentang angka 0,000-0,499. Artinya bahwa ketersediaan ruang terbuka kota Selong berada pada kategori rendah, dengan kata lain ketersediaan ruang terbuka olahraga kota selong masih belum memadai.Oleh karena itu pemerintah kota Selong diharapkan dapat memperluas ruang terbuka olahraga untuk masyarakat dengan membangun berbagai sarana/prasarana olahraga baik indoor maupun outdoor sesuai dengan kebutuhan olahraga masyarakat kota Selong.

2. Indeks partisipasi masyarakat Kota Selong ialah 0,332. Nilai indeks ini lebih tinggi dibandingkan nilai indeks partisipasi nasional yaitu 0,422. Namun jika ditinjau dari SportDevelopment Index dan berdasarkannorma SDI, nilai indeks ini masih berada pada rentang angka 0,000-0,499. Artinya bahwa tingkat partisipasi masyarakat kota Selong dalam berolahraga masih rendah atau berada pada kategori rendah.

3. Indeks pembangunan olahraga (SDI) Kota Selong yaitu 0,302. Nilai indeks SDI ini lebih tinggi dari nilai indeks SDI Nasional tahun 2006 dengan nilai indeks 0,280. Namun jika dilihat dari norma SDI untuk mengkategorikan indeks SDI, maka nilai indeks SDI Kota Selong masih berada pada ketegori rendah karena indeksnya masih berada di bawah nilai SDI

\section{Daftar Pustaka}

Albertus F. 2013. Manajemen Konflik dalam Olahraga ; Solusi Pemecahan Konflik dalam Dunia Olahraga di Indonesia. Surabaya : Graha Media.

Arikunto S. 2010. Prosedur Penelitian, Suatu Pendekatan Praktik. Jakarta :RinekaCipta.

Firianto, Deny. Mengukur Pembangunan Olahraga .(http://www.mengukur Pembangunan Olahraga.com/Suara Guru/html).

Gichara J. 2009. Jalan Sehat untuk Kebugaran dan Kekuatan Tubuh. Jakarta: Kawan Pustaka.

Hamdi M. 2014. Kebijakan Publik; Proses, Analisis, dan Partisipasi. Bogor : GhaliaIndonesia.

Harsuki. 2012. Pengantar Manajemen Olahraga.Jakarta :Raja Grafindo Persada.

Huraerah, Abu. 2008. Pengorganisasian dan Pengembangan Masyarakat. Bandung Humaniora.

Hari Gunawan. Pemberdayaan SDM untuk mendukung Olahraga Sebagai Industri Masa Depan. (http://ikipmataram.ac.id/berita-368-pemberdayaan-sdm untuk--mendukungolahraga--sebagai--industri-masa-depan.html).

Kamaluddin Rustian. 1987. Beberapa Aspek pembangunan Nasional dan PembangunanDaerah. Jakarta : Fakultas Ekonomi Universitas Indonesia.

Kristiyanto, A. 2012. Pembangunan Olahraga : untuk Kesejahteraan Rakyat dan Kejayaan Bangsa, Surakarta : Yuma Pustaka. 
Kristiyanto, A. 2013. Riset Futuristik Keolahragaan; Inspirasi Substansi dan Metodologi. Yogyakarta : Graha Ilmu.

Mutohir dkk. 2011. Berkarakter dengan Berolahraga Berolahraga dengan Berkarakter.Surabaya : SPORT Media.

Mutohir dkk. 2007. Sport Development Index: Alternatif Baru Mengukur Kemajuan Pembangunan Bidang Keolahragaan (Konsep, Metodologi dan Aplikasi). Jakarta : Index.

Nurcholis H. 2009. Pedoman Pengembangan Perencanaan Pembangunan Partisipasi Pemerintah daerah; Perencanaan Partisipasi Pemerintah Dearah. Jakarta : Grasindo.

Nurhasan. 2001. Tes Pengukuran dalam Pendidikan Jasmani. Jakarta : Depdiknas.

Noor Isran. Daerah Maju Indonesia Maju; Strategi Pembangunan yang Mensejahterakan dan Berkeadilan. 2013 : Grafindo.

Pandjaitan, Hinca IP. 2011. Kedaulatan Negara VS Kedaulatan FIFA: Bagaimana mendudukkan masalah PSSI dan Negara. Jakarta: Gramedia Pustaka Utama.

Renstra KEMENPORA .2010-2014. Pdf. Undang-Undang Republik Indonesia Nomor 3 Tahun 2005 Tentang Sistem Keolahragaan Nasional, jakarta; Biro Humas dan Hukum Kementrian Negara Pemuda Olahraga Republik Indonesia, 2007.

Wahjoedi. 2000. Tes Pengukuran dalam Pendidikan Jasmani dan Olahraga. Ujung Pandang : Singaraja. 